\title{
Relationship between children's theory of mind and metalinguistic competence in early childhood
}

\author{
Department of Psychology, Faculty of Arts, University of Ljubljana, Slovenia
}

\begin{abstract}
The aim of this study was to examine the relations between the theory of mind and metalinguistic competences in early childhood. The sample included 45 children aged from 4;6 to 6 years from 5 different Slovene preschools. The False belief task and the Pictures sequencing task were used to assess children's theory of mind. Children's metalinguistic competences were assessed with the Little glove storytelling test and the Scales of general language development. Children's parents also completed a questionnaire, designed to obtain information about children's play. The results showed significant correlations between children's scores on the majority of tasks. A significant relationship was found between children's theory of mind, their metalinguistic awareness and their storytelling competence, especially the content structure of their story. This association might reflect similar demands for children's understanding of representations that is necessary for the theory of mind and metalinguistic competences. Furthermore, there was no significant correlation between the scores on the Picture sequencing task and children's false belief understanding, but there was a significant correlation between these scores and children's scores on the tasks of metalinguistic competences, which could be an indicator of a relation between child's sequencing of pictures into a complete story and their metalinguistic competences. Results did not show significant differences between children's theory of mind or their metalinguistic awareness based on the type of their most frequent play. Thus, the study provides a complex insight into relations between different aspects of children's theory of mind and metalinguistic competences; and as such highlights the strong relationship between both constructs.
\end{abstract}

Keywords: theory of mind, metalinguistic competence, metalinguistic awareness, storytelling, early childhood

\section{Povezave med teorijo uma in metajezikovnimi zmožnostmi pri otrocih v zgodnjem otroštvu}

\author{
Kaja Hacin* \\ Oddelek za psihologijo, Filozofska fakulteta, Univerza v Ljubljani
}

\begin{abstract}
Povzetek: Namen pričujoče raziskave je bil podrobneje preučiti povezave med teorijo uma in metajezikovnimi zmožnostmi pri otrocih v zgodnjem otroštvu. V raziskavo je bilo vključenih 45 otrok, starih od 4;6 do 6 let, ki so prihajali iz 5 različnih slovenskih vrtcev. Za ocenjevanje teorije uma smo uporabili Nalogo napačnih prepričanj in Preizkus razvrščanja slik, za ocenjevanje metajezikovnih zmožnosti pa Lestvice splošnega govornega razvoja in Preizkus pripovedovanja zgodbe - Rokavička. Poleg tega je bil uporabljen tudi vprašalnik za starše, namenjen zbiranju informacij o igri otrok. Rezultati so pokazali pomembno povezanost med dosežki otrok pri večini uporabljenih preizkusov. Kot pomembna se je kazala medsebojna povezanost otrokove teorije uma z metajezikovnim zavedanjem in pripovedovanjem zgodbe, še posebej z vidika vsebinske strukture zgodbe. Povezave med navedenimi zmožnostmi lahko kažejo na podobne zahteve po otrokovem razumevanju reprezentacij, ki ga predvidevajo otrokova teorija uma in metajezikovne zmožnosti. Poleg tega se dosežki pri Preizkusu razvrščanja slik niso pomembno povezovali z otrokovim razumevanjem napačnih prepričanj, so se pa ti dosežki pomembno povezovali z otrokovimi dosežki pri preizkusih metajezikovnih zmožnosti, kar kaže na povezanost med otrokovim razvrščanjem slik v celovito zgodbo in njegovimi metajezikovnimi zmožnostmi. Rezultati pa niso pokazali pomembnih razlik v teoriji uma otrok glede na njihovo najpogostejšo vrsto igre. Raziskava nudi celovit pregled odnosov med različnimi vidiki teorije uma pri otrocih in njihovimi metajezikovnimi zmožnostmi ter kot taka opozarja na tesno povezanost obeh konstruktov.
\end{abstract}

Ključne besede: teorija uma, metajezikovne zmožnosti, metajezikovno zavedanje, pripovedovanje zgodbe, zgodnje otroštvo \footnotetext{
hacin.kaja@gmail.com

Članek je licenciran pod pogoji Creative Commons Attribution 4.0 International licence (CC-BY licenca).

The article is licensed under a Creative Commons Attribution 4.0 International License (CC-BY license).
}

*Naslov/Address: Kaja Hacin, Oddelek za psihologijo, Filozofska fakulteta, Univerza v Ljubljani, Aškerčeva 2, 1000 Ljubljana, e-pošta: 


\section{Theory of mind and early childhood}

Theory of mind is the ability to understand and perceive yourself and others as people who have their own beliefs, emotions, wishes, and interpretations of the world (Marjanovič Umek, 2009). It is a development of a child's ability to understand human behaviour with the recognition and attribution of mental states to people (Jenkins \& Astington, 1996). The most often researched ability within the concept of theory of mind is the false belief understanding. According to Wellman, Cross, and Watson (2001), the reason for this is that a child's understanding of the false belief - one whose content contradicts reality - provides compelling evidence that a child can appreciate the difference between the mind and the real world and with that shows the understanding of mental states as interpretations of reality. A great number of different standard tasks exist for assessing one's theory of mind, e.g. Change in location task (Baron Cohen, Leslie, \& Frith, 1985; Wimmer \& Perner, 1983) in which a child has to understand that the protagonist's belief is a mental state that represents something and can be different from reality (Perner, 1991). Children usually pass standard false belief tasks between the ages of 4 and 5 years. Consequently, many researchers (e.g. Gopnik \& Astington, 1988; Slade \& Ruffman, 2005; Wellman et al., 2001) claim that there is a conceptual shift in the child's understanding of human behaviour at that age. At the same time, Astington (2001) stresses that beside the false belief understanding, theory of mind consists of many other abilities, for example understanding of intentions and wishes. The theory of mind develops gradually through early childhood and can include different aspects of cognitive development at different ages.

With more frequent research of theory of mind there are also more and more critiques about standard tasks used for assessing theory of mind, especially from the aspect of language competences the tasks require (Bloom \& German, 2000; Call \& Tomasello, 1999). Baron Cohen, Leslie, and Frith (1986) wanted to create a theory of mind task that would differ from other standard task in its demands. They created the Pictures sequencing task, in which a child has to sequence pictures into the correct order to form a cohesive story. The authors assumed that correctly sequenced pictures reflect the child's understanding of the story that is shown in the pictures. They used different types of stories, one of which included recognition and attribution of mental states to the protagonists. The child's performance in that type of stories is an indicator of their theory of mind.

\section{Children's metalinguistic competences}

Some of the most important correlates of children's theory of mind are their language competences (Milligan, Astington, \& Dack, 2007). Past researches (e.g. Astington \& Jenkins, 1999; Cutting \& Dunn, 1999; Jenkins \& Astington, 1996; Slade \& Ruffman, 2005) have shown correlations between children's theory of mind and their language competences. The child's theory of mind is associated with their semantic, grammatical and pragmatic language competences. In addition, different studies (e.g. Doherty \& Perner, 1998;
Hughes \& Dunn, 1998) found important correlations between theory of mind and various metalinguistic competences of children in early childhood. Some researchers (e.g. Farrar \& Ashwell, 2012) emphasize the importance of theory of mind for the development of metalinguistic competences, especially metalinguistic awareness.

Metalinguistic competences enable children representation of their thought, development from the concrete to the representation stage of the mind, the application of the language to express emotions, wishes and intentions, and the understanding of their own and others' mental processes. Metalinguistic competences include different competences. One of the possible classifications is dividing metalinguistic competences to metalinguistic awareness, metacommunication and metavocabulary. Metalinguistic awareness refers to one's awareness of language units (e.g. words, syllables) and to the awareness of relations between words, their meaning and syntax. Metacommunication is the development of children's pragmatic awareness that allows them to communicate about objects, events and people that are not present in that precise moment and space. Metavocabulary is the children's use of terms for mental states; for example, verbs "thinking", "knowing", nouns "thought", "wish" etc. (Marjanovič Umek \& Fekonja Peklaj, 2010).

As stated, metalinguistic awareness is the competence to reflect the language as the communicational tool and oneself as the user of the language (Marjanovič Umek \& Fekonja, 2009); it is the awareness of the language as language. That is, a child must not only be able to attend to the form of the language, but must also be aware of its function, to carry meaning (Doherty \& Perner, 1998). For example, the word "sock" is short even though the actual object "sock" is long. Metalinguistic awareness includes different components, such as phonological awareness (Farrar, Ashwell, \& Maag, 2005), grammatical awareness (de Villiers \& de Villiers, 1972) and semantic awareness (Doherty \& Perner, 1998). The metalinguistic awareness develops gradually, but the central feature of it, understanding language as language, develops around the age of 4 years (Doherty \& Perner, 1998). Both theory of mind and metalinguistic awareness are associated with the ability to understand the representational nature of the mind. Studies show that children's theory of mind is associated with their semantic awareness, for example with understanding of synonyms and homonyms (Doherty, 2000; Doherty \& Perner, 1998), and with their phonological awareness, even when the age, language competences and memory of children are controlled (Ferrar et al., 2005). To explain these results, Doherty and Perner (1998) proposed the »representational understanding of mind « hypothesis, which states that a child's understanding of mental states as representations can be applied to non-mental representations. In the tasks of homonyms and synonyms, the child has to differentiate between what is represented (meaning) and how it is represented (word form). Similarly, the child has to, in the false belief task, understand two different representations (beliefs) of the situation. On the other hand, Perner, Stummer, Sprung, and Doherty (2002) claim that the false belief tasks and synonym task all require a child's ability to switch between different perspectives. A child has to be able to understand different perspectives of the same word 
or situation and at the same time he has to be able to switch between those perspectives, ignoring one perspective while focusing on the other. Some authors (e.g. Farrar et al., 2005; Farrar \& Ashwell, 2012) claim the relation between theory of mind and metalinguistic awareness is the consequence of the same executive functions that lay in the background of both types of tasks. These authors highlight different executive functions are the key functions; for example, control of inhibition (Farrar \& Ashwell, 2012) and cognitive flexibility (Farrar et al., 2005). However, the results of these studies do not show a clear picture about the importance of executive functions for the theory of mind and metalinguistic awareness.

Beside metalinguistic awareness, there are also some other aspects of children's metalinguistic competences, for example storytelling (Charman \& Shmueli Goetz, 1998). Developmental stage of the story is typically assessed with the story's cohesiveness (it has to have a logical structure in which all the events and causal relations are represented appropriately) and its coherence (it has to be well-integrated) (Marjanovič Umek \& Fekonja, 2009). The child's conventional story includes important components, such as the ability of representation, decentralization, and understanding of different perspectives, a metavocabulary, and the ability to connect events, emotions, thoughts and relations of the protagonist (Applebee, 1978). According to this, children can use their mental representations while telling a story (Marjanovič Umek \& Fekonja Peklaj, 2010). There is evidence for the relation between children's storytelling and their theory of mind. Charman and Shmueli Goetz (1998) discovered that children's theory of mind is associated with their ability to change perspectives between different protagonists in the story and with their referential strategy when introducing a new story character. In addition, the relation between theory of mind and storytelling could originate from a child's use of mental states terms. The increased frequency of descriptions of the protagonist's mental states in the stories of 4- and 5years olds could be a sign of theory of mind development (Marjanovič Umek et al., 2010).

Mental states terms are terms which are used for describing different mental states; for example, »think«, »want«, »know« (Hughes \& Dunn, 1998). They are considered to be metarepresentational expressions, since it is assumed that in order to understand them and to use them correctly, the individual must represent the representational attitude that such verbs involve (that is, knowing, wishing) and the content of the representational state (that is, what is known or wished) (Antonietti, Liverta Sempio, Marchetti, \& Astington, 2006). Children start to use these terms when they are 3 years old. At the beginning they use these terms incorrectly, but during the fourth year they start to use them more frequently and correctly (de Villiers, 2007). Consequently, we can say that children use mental states terms before they really understand them (Miller, 2006). Previous studies show (e.g. Antonietti et al., 2006; Hughes \& Dunn, 1998) that children's use of mental states is associated to their theory of mind.

A lot of different researchers claim that the symbolic play is a suitable context for the development of child's theory of mind (e.g. Leslie, 1987; Perner, 1991, Perner, Baker, \& Hutton, 1994) and their metalinguistic competences (e.g. Marjanovič Umek \& Fekonja, 2009; Marjanovič Umek \& Lešnik Musek,
1999). Symbolic play is a type of playing in which a child exceeds the present situation, time and space (Fekonja, 2009). It includes an act of pretending, in which a child deliberately contradicts the real situation and transforms it. It requires abilities of internal representations (Leslie, 1987) and acting »as if«, which are both important for false belief understanding. In addition, children use metacommunication to form a frame of a symbolic play, to transform different objects and to direct their play (Marjanovič Umek \& Fekonja, 2009).

The aim of this study was to examine the relation between children's theory of mind and different aspects of their metalinguistic competences. Previous studies focused on this relation mostly by using the standard theory of mind tasks and tasks for assessing children's metalinguistic awareness. However, they rarely included other aspects of metalinguistic competences, such as children's storytelling or use nonstandard theory of mind tasks. At the same time, the results of previous studies do not clearly show the importance of the relation between a child's theory of mind and their metavocabulary or metacommunication. Therefore, we first wanted to examine the relation between different tasks used for assessing the theory of mind. Second, we wanted to examine the relations between children's theory of mind and their metalinguistic competences, assessed with storytelling, metalinguistic awareness and metavocabulary. In accordance with this, we wanted to include different aspects of storytelling to determine the role of the story's coherence and cohesiveness in relations to theory of mind and metalinguistic awareness. At the same time, we wanted to examine the relation between a context where metacommunication is used, i.e. symbolic play, theory of mind and metalinguistic awareness.

\section{Method}

\section{Participants}

The sample included 45 children aged from $4 ; 6$ to $6 ; 0$ years $(53,3 \%$ girls and $46,7 \%$ boys) from 5 different Slovenian preschools. The average age was 5 years and 1 month $(S D=5$ months). All children spoke Slovenian as their first language.

\section{Instruments and task procedure}

We wanted to assess children's theory of mind from different perspectives, so we used one of the standard theory of mind tasks, i.e. the Change-in-location false belief task (Baron Cohen et al., 1985), and one of non-standard theory of mind tasks - the Pictures Sequencing task (Baron Cohen et al., 1986). For the purpose of assessing metalinguistic competences, we used the Scales of general language development (Marjanovič Umek, Fekonja, Podlesek, Kranjc, \& Bajc, 2007) and the Little glove storytelling test (Marjanovič Umek, Fekonja Peklaj, Sočan, \& Komidar, 2011). We also formed a questionnaire for parents with the aim to obtain information about children's play. Additionally, we examined the number of mental state terms each child used during the performance on all used tasks, which represented an indicator of their metavocabulary. 


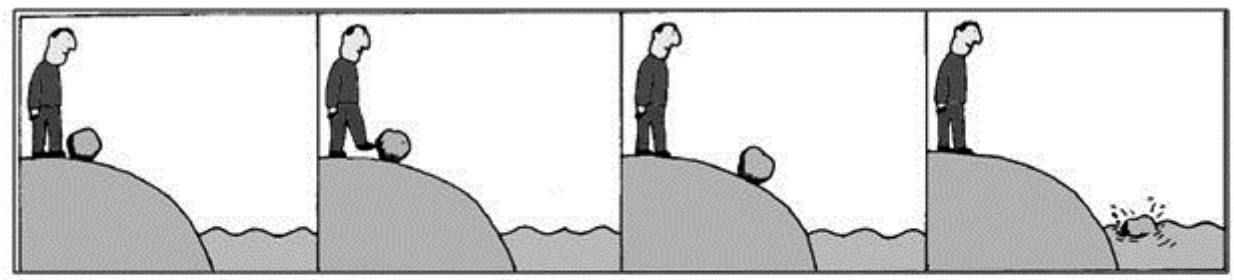

(a)

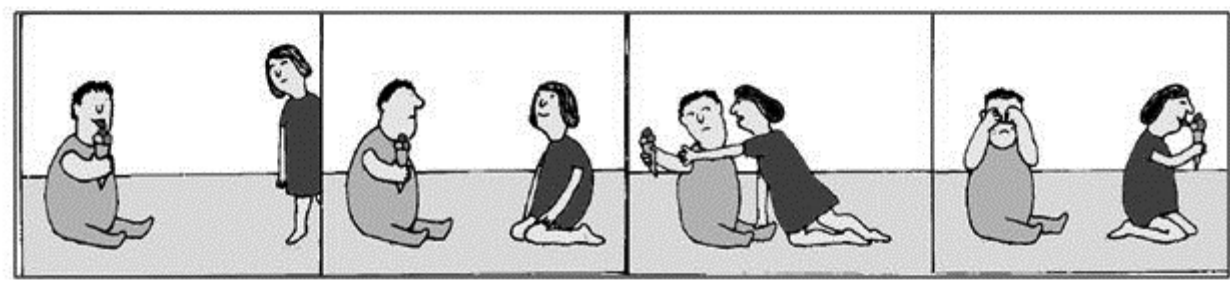

(b)

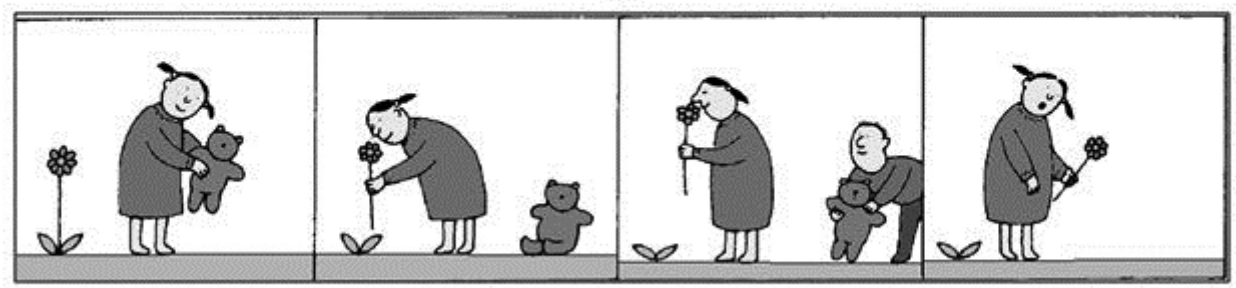

(c)

Figure 1. Used picture sequences: (a) mechanical story; (b) behavioural story; (c) intentional story. Reprinted from "Mechanical, behavioural and Intentional understanding of picture stories in autistic children" by S. Baron Cohen, A. M. Leslie and U. Frith, 1986, British Journal of Developmental Psychology, Volume 4, p. 116. Copyright 1986 by the British Psychological Society. Reprinted with permission. All rights reserved.

False belief task. For the purpose of assessing children's theory of mind the False belief task (Change in location task) was used (FBT; Baron Cohen et al., 1985), which measures children's false belief understanding. We used different toys to play a scene in front of a child. The scene included two girls, Nika and Sara (Slovenian names were given to the girls for the purpose of this study), that play together with a ball. Nika has to go home, so she puts the ball into a box. When she is away, Sara moves the ball from the box and hides it under a plastic jar. Afterwards, Nika comes back and she wants to play with the ball. At this point, we first asked the child where Nika will look for the ball and then why (two test questions). We also asked two control questions regarding the initial location and the actual location of the ball to test the child's attention and recollection. The child's answers to test questions were scored if the child answered correctly to both control questions. A child could get from 0 to 2 points; 1 point for each correct answer to the test questions.

Pictures sequencing task. The Picture sequencing task (PST) is the task formed by Baron Cohen and colleagues (1986) and it assesses a child's ability to sequence pictures into correct order to form a story. Each story is composed of 4 pictures. The assumption is that the correctly sequenced pictures reflect the child's understanding of the story shown in the pictures. At the same time, the child's understanding is assessed with the narrative, which the child bases on the pictures. The stories included in the task were of 3 different types: mechanical (the sequence can be understood in terms of causal-mechanical criteria), behavioural (the sequence can be understood in terms of descriptive-behavioural criteria), and intentional (the understanding of the sequence requires attribution of mental states). The main assumption of the task is that the correct sequence of the pictures in the intentional story is the indicator of a child's theory of mind. All stories are shown in Figure 1.

At the beginning, we placed the four pictures in mixed order in front of the child (the order of pictures at the beginning was the same for all children) and gave him the instructions: "Take a good look at these pictures and try to make a story with them." When sequencing the pictures, the child had to move them in the space below the initial row where they were positioned. The order of presentation of different story types was always the same, like the authors of the task predicted (i.e. mechanical, intentional, behavioural story). The child was able to get 2 points for each story ( 2 points for the correct order of all the pictures, 1 point for the correct order of the end ones and 0 points for all other orders).

When the child finished with the picture sequencing and was satisfied with their order, he got the instructions to "tell the story about what happened in the pictures". Children's narratives were later classified into one of three categories: causal (narrative includes causal relationships), mental state (mental states of protagonists were expressed in narration) or descriptive (all others). For this classification, merely the surface form of the verbal utterances was looked at and the correctness of the previous sequencing had no effect. 
Examples for each category are (all for the intentional story):

- Causal: "First she was playing with the bear, then she took the flower and the bear was gone because he took it."

- Mental state: "She put the bear here and she took the flower, then that boy took the bear and she did not see it and she did not know where the bear is."

- Descriptive: "She smelt the flower, then another one grew, then she took it, then the boy came. Then he went away and the girl went too."

Scales of general language development. Scales of general language development (Lestvice splošnega govornega razvoja, Marjanovič Umek et al., 2007) is a standardized assessment tool for assessing the general language development of toddlers and children from ages of 2 to 7 years. It includes 3 different scales: Language comprehension scale, Language expression scale and Metalinguistic awareness scale. For the aims of this study, we used only the Metalinguistic awareness scale (MAS) and one task from the Language comprehension scale: the Brundo's evening task.

The $M A S$ assesses children's metalinguistic awareness. It includes different types of tasks, in which a child has to, for example, recognize the first and last sounds of a word, compare words based on their length, correct grammatical mistakes etc. The maximum number of points is 35 points. According to the Manual of Scales of general language development (Marjanovič Umek et al., 2007) the $M A S$ has high reliability ( $\alpha=0.88$ for 5 -year-olds).

The Brundo's evening task is a task from the Language comprehension scale and it assesses a child's comprehension of the read text about little bear Brundo and his evening. A child shows his understanding of the story by sequencing 4 pictures, which show different events of the little bear's evening into the correct order - as they happened in the story (see Figure 2). For the aims of this study, we added another part to the Brundo's evening task. That is, after sequencing the pictures, children had to tell the story of Brundo's evening on their own. That way, we formed new Brundo's evening task $(B E T)$, which consisted of two parts. The first part of BET that was the same as in the original task from the Language comprehension scale was named BET-understanding. The children could get 0 or 4 points on this part -4 points if they sequenced the pictures correctly and 0 points if the order was not correct. The second part of BET that included the child's later storytelling, based on the pictures, was named $B E T$ - storytelling. Even though the BET-storytelling is not a part of the Scales of general language development, we used the same criteria for assessing children's storytelling as they are defined in the Manual of Scales of general language development (Marjanovič Umek et al., 2007) for the storytelling task that is a part of the Language expression scale. According to this, the child's story was assessed based on its coherence and cohesiveness. The maximum amount of points for coherence was 5 points and for cohesiveness 4 points. The sum of both was the child's general score on the BET - storytelling. We decided to use this task because its demands are very similar to the demands of PST. In both tasks a child has to sequence 4 pictures in the way that they form a story. The only difference is that in BET a child has to do that based on the story that is read to them and in PST they have to form a story by themselves.

Little glove storytelling test. Little glove storytelling test (LGST; Preizkus pripovedovanja zgodbe - Rokavička, Marjanovič Umek et al., 2011) is a standardized instrument that is used for assessing the storytelling of children aged from 3 to 6 years. Children tell the story using a picture book with 11 illustrations. We assess children's stories based on 11 different criteria, which can be combined into three partial scores: vocabulary, grammatical structure of the story, and content structure of the story. According to the Manual of Little glove storytelling test (Marjanovič Umek et al., 2011) the LGST has high reliability $(\alpha=0.88)$. In addition, the correlation between two independent assessors found in the process of standardization was high $(r=0.98)$.

For the purposes of this study we assessed grammatical structure (average length of sentences, number of compound sentences, percent of simple sentences, usage of subordinating and coordinating conjunction) and content structure (number of events, number of shifts in perspective and number of used mental state terms) of children's stories. Each criterion represented a separate score. In addition, we calculated the
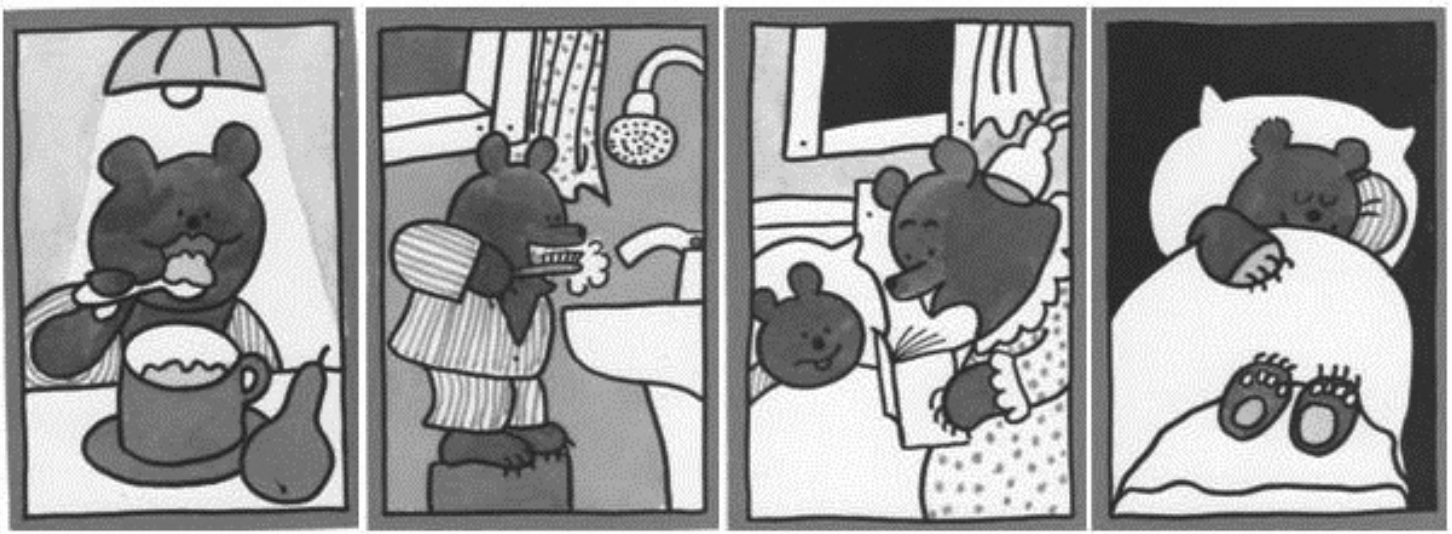

Figure 2. Pictures used for BET. Pictures show the events of little bear Brundo's evening as they are described in the story that was read to children (Marjanovič Umek et al., 2007). 
sum of scores for grammatical structure (LGST - grammar) and for content structure (LGST-content).

The questionnaire for parents. Finally, we formed a questionnaire for parents to gather some additional information about the children's most frequent play. Parents had to answer two questions pertaining to their child's play. First question was: "What type of play does your child spend the most time playing?" Parents had to choose one of four different types of play: constructive play, symbolic play, games with rules or motor play. Each one had also written a concrete example of children's play. The second question required an open description of a child's most typical play. The instruction was: "Please, form a short description of your child's most frequent play." Based on this description we classified the answers in one of four different types of play (constructive play, symbolic play, games with rules or motor play).

\section{General procedure}

The parents of all participating children gave their written consent, allowing their children to participate in the study, and they filled in the questionnaire. Children were then tested individually in a quiet room in their preschool.

To avoid any unwanted effects between different tasks, we formed 8 different orders of all tasks. More specifically, we divided all of the tasks into two groups: a group for assessing theory of mind (FBT and PST) and a group for assessing metalinguistic competences (BET, MAS and $L G S T)$. Half of the children were assessed using the theory of mind tasks first and then the metalinguistic competences tasks and the other half were assessed with the opposite order. During this, we were also changing the order of tasks within each task group.

\section{Results}

We used the Shapiro-Wilk test for testing the normality of the distribution of assessed variables, which showed that children's scores on the majority of the used tasks were not distributed normally (exceptions were general score at $L G S T$ content and general score at $L G S T$-grammar). Consequently, we used non-parametric tests; more specifically, we used Spearman's correlation coefficient and Kruskal-Wallis test. Below, we first present the average scores and other descriptive statistics of collected data. Following that, we present the correlations between children's performance on different tasks used for assessing theory of mind and metalinguistic competences.

\section{Descriptive statistics}

Firstly, we looked at the average scores of the children on all used tasks. In the PST, the scores from different stories were correlated, so we also calculated children's general score on this task. The average scores from each task can be seen in Table 1.

We can see in Table 1 that the children's scores on FBT are quite high. Besides from the high average score on this task, a high percent of children also answered correctly where the girl would look for her ball $(80.0 \%)$. At the same time, more than half of them $(60.0 \%)$ also correctly explained why she would look for it there. On average, children scored low on the PST. Their scores are relatively low in all of the stories and often they also had problems when they were performing it. Children got the highest scores for the mechanical story, followed by the intentional story, and at the behavioural story their scores were the lowest. A similar pattern was observed with regard to the percentage of children that correctly sequenced all the pictures, as $17.8 \%$ of children correctly sequenced all pictures in the mechanical story, $8.9 \%$ in the intentional story and $2.2 \%$ in the behavioural story. Moreover, more than one third of the children $(37.8 \%)$ did not even change the order of the pictures at all and instead said that the original order was correct. At the BET - understanding we also examined the successfulness of children's performance at sequencing the pictures. There were $26.7 \%$ of children that correctly sequenced all four pictures. When we analysed the mistakes in the children's performance, we saw that $22.2 \%$ of the children that were not successful at this task did not change the order of pictures at all.

In case of the PST, we also examined children's storytelling based on the surface form of their narrations. According to this, every narration was categorized into one of three different categories: causal (the story consisted of causal relations), mental state (the story consisted of mental states of protagonists) or descriptive (all other stories). The percentage of stories that were categorized in each category in each type of the stories is shown on Figure 3. Figure 3 shows that the majority of children's narrations at the mechanical

Table 1. Children's average score on each task and their subscales

\begin{tabular}{lrrr}
\hline & max. & & \\
& score & \multicolumn{1}{c}{ M } \\
\hline$F B T$ & 2 & 1.40 & 0.81 \\
$P S T$ & 6 & 1.29 & 1.42 \\
Mechanical story & 2 & 0.58 & 0.78 \\
Behavioural story & 2 & 0.29 & 0.51 \\
Intentional story & 2 & 0.42 & 0.66 \\
$M A S$ & 35 & 9.24 & 4.78 \\
$B E T-$ understanding & 4 & 1.07 & 1.79 \\
$B E T-$ storytelling & 9 & 6.69 & 0.73 \\
Coherency & 5 & 2.96 & 0.52 \\
Cohesiveness & 4 & 3.73 & 0.45 \\
$L G S T-$ content & $/$ & 6.84 & 3.04 \\
Number of mental state terms & $/$ & 1.31 & 1.14 \\
Number of events & 14 & 5.00 & 2.22 \\
Number of shifts in perspective & 4 & 0.53 & 0.66 \\
LGS - grammar & $/$ & 19.80 & 5.68 \\
Average length of sentences & $/$ & 10.74 & 2.50 \\
Number of coordinate clauses & $/$ & 4.16 & 2.55 \\
Number of subordinate clauses & $/$ & 3.67 & 3.30 \\
Percent of simple sentences & 1 & 0.47 & 0.19 \\
\hline
\end{tabular}

Note: max. score $=$ maximum number of points for each task and the task's scale or criterion. For the criteria, where the maximum number of points cannot be defined, the symbol / is used. 


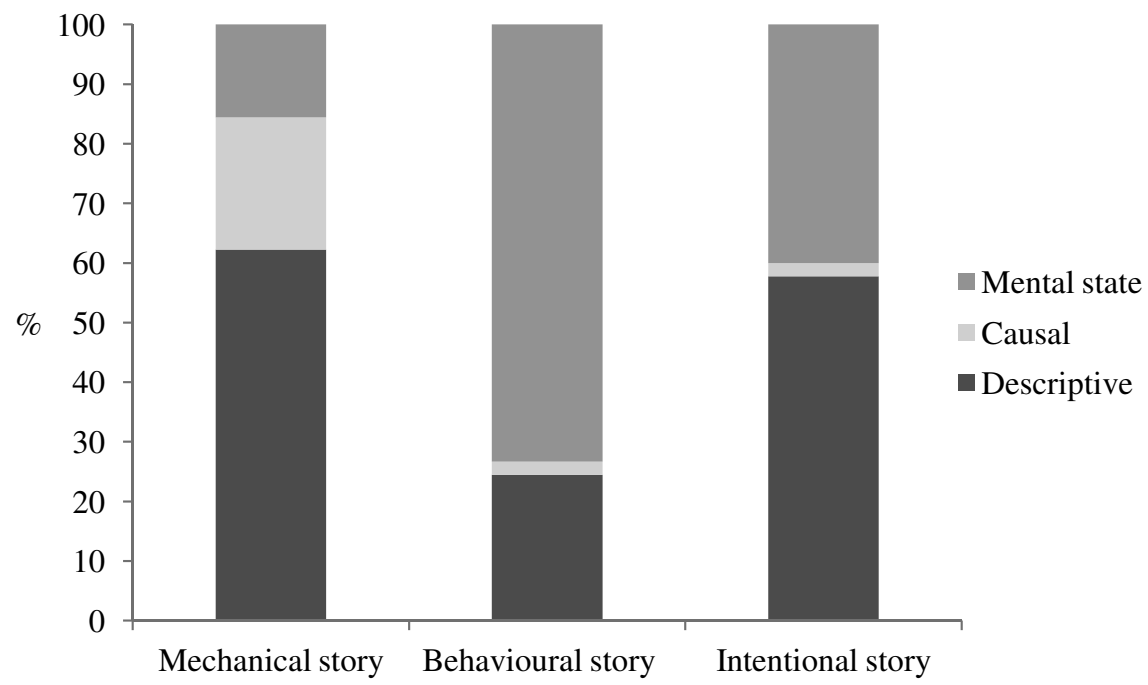

Figure 3. The percentage of stories categorized into each category for all types of stories.

and intentional stories were classified as descriptive. At the same time, the children's narrations at the behavioural story were most often put into the mental category, which was quite frequent at the intentional story too.

Further, we analysed parents' answers about children most typical play. Figure 4 shows the percentage of children who spend most time in each type of play for both questions separately. We can see in Figure 4 that the most frequent type of play was symbolic play followed by motor play, which was especially frequent in the case of close-ended question. We can also see that there are quite big differences between answers on each of the two questions. Constructive and symbolic play seemed to be more frequent and motor play seemed to be less frequent when parents had to form an open description of play. When comparing the two types of answers we found out that parents often define any play that children play outside as motor play, even thought it had clear indicators of symbolic play. Because of these inconsistencies the information that we gathered about children's play could be problematic.

\section{Associations between performance on tasks used for assessing theory of mind and metalinguistic competences}

At the beginning, we examined the children's performance on both tasks for assessing the theory of mind. We found a positive correlation between the children's scores on FBT and their scores on the intentional story at PST, but the correlation was not significant $(\rho=0.18, p=0.24)$. The correlation between the children's scores on FBT and their general scores on PST was a bit higher, but it was also not significant $(\rho=0.27, p=0.08)$. To conclude, our data shows positive correlations between children's performance on FBT and PST, but they are not significant.

Following this, we examined the correlations between children's scores on all tasks that we used, which are presented in Table 2. As we can see in Table 2, there are significant positive correlations between the children's scores

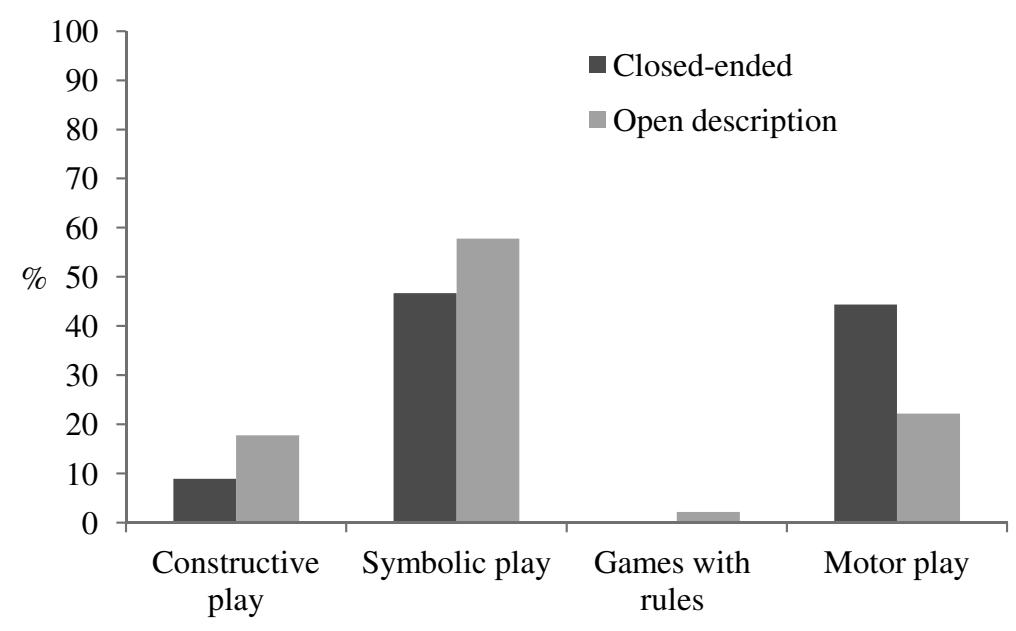

Figure 4. The percentage of children that spend the most time in each type of play. Close-ended=close-ended question where parents chose children's most typical type of play by themselves; open description = type of play determined based on open description of children's most typical play written by their parents. 
Table 2. Correlations (Spearman's rho) between children's scores on all used tasks

\begin{tabular}{|c|c|c|c|c|c|c|}
\hline & FBT & PST & MAS & $\begin{array}{c}\text { BET - } \\
\text { understanding }\end{array}$ & $\begin{array}{c}\text { BET - } \\
\text { storytelling }\end{array}$ & $\begin{array}{c}\text { LGST - } \\
\text { content }\end{array}$ \\
\hline PST & .27 & & & & & \\
\hline MAS & $.31^{*}$ & $.32^{*}$ & & & & \\
\hline BET - understanding & .16 & .14 & .16 & & & \\
\hline $\mathrm{BET}-$ storytelling & $.55^{* *}$ & .25 & $.36^{*}$ & $.46^{* *}$ & & \\
\hline LGST - content & $.41^{* *}$ & $.34^{*}$ & $.41^{* *}$ & $.38^{*}$ & $.64^{* *}$ & \\
\hline LGST - grammar & .11 & .12 & .23 & $.41^{* *}$ & $.36^{*}$ & $.61^{* *}$ \\
\hline
\end{tabular}

${ }^{*} p<.05 ;{ }^{* *} p<.01$.

on the different tasks that we used. Children's performance on both tasks used for assessing storytelling (BET and LGST) was significantly correlated and the correlations were mostly moderate. Metalinguistic awareness, assessed with $M A S$, was significantly correlated with the children's storytelling, more specifically with the content structure of the story. In general, we can see that all of the children's scores on tasks for assessing metalinguistic competences are significantly correlated. The only exceptions are children's performances on LGST-grammar and BET-understanding, as the scores on these two tasks are not significantly correlated with the children's metalinguistic awareness assessed with MAS.

We then examined the correlations of the children's scores on FBT and PST with their scores on the tasks used for assessing metalinguistic competences. When compared, we can see that both children's scores (on FBT and on PST) are significantly correlated with their scores on $M A S$ and $L G S T$ - content. However, at the same time, they are not correlated significantly with their scores on BET-understanding or LGST-grammar.

Finally, we examined the correlations between each criterion of the story at LGST - content and children's performance on $M A S, F B T$ and $P S T$. The criterion of the story content that stood out is the number of events that the children included in their stories, because it was significantly correlated with children's scores on $\operatorname{MAS}(\rho=0.37, p<0.05)$, on $\operatorname{FBT}(\rho=0.48, p<0.05)$ and also on PST $(\rho=0.40, p<0.05)$. While examining the story's criterion of the number of shifts in perspective we found that the only significant correlation with this criterion was the one with children's scores on $M A S$ $(\rho=0.29, p=0.05)$. On the other hand, this criterion was not significantly correlated with children's scores on FBT $(\rho=$ $0.25, p=0.10)$ or PST $(\rho=0.17, p=0.26)$.

Regarding the use of mental state terms, we recorded the children's use of these terms by counting how many mental state terms each child used. In the entire performance of all tasks, children used, on average, 3 terms for mental states ( $M$ $=3.16, S D=1.82$ ). From the viewpoint of relations between the child's false belief understanding and their use of mental state terms, we found no significant correlations between the children's performance on FBT and their use of these terms $(\rho=0.15, p=0.33)$. Because children often used one and the same term multiple times, we also examined the relation between different mental state terms used and children's scores on $F B T$. On average, children used two different mental state terms $(M=2.16, S D=1.15)$. The correlation between the children's scores on $F B T$ and the number of different terms they used was higher than the correlation with the absolute number of used terms, but it was still not significant $(\rho=0.23$, $p=0.13$ ).

At the end, we analysed the relation between the children's performance on $F B T$ and $M A S$ and their most frequent type of play. Kruskal-Wallis test was conducted to compare the effect of children's most frequent type of play (constructive play, symbolic play, games with rules or motor play) on their performance on $F B T$ and $M A S$. The results showed that there was no significant difference in the children's performance on FBT, based on their most frequent type of play, $\chi^{2}(2)=$ $0.915, p=0.63, \eta^{2}=0.021$. Additionally, we defined the type of the children's most typical play based on the parent's open descriptions of their children's play. In accordance with previous findings, there were no significant differences between children's scores on FBT between different types of the most typical play, $\chi^{2}(3)=1.261, p=0.738, \eta^{2}=0.029$.

Similarly, we examined the differences between children's performance on $M A S$ depending on most frequent type of their play. There were no significant differences found between the children's performance on $M A S$ - when the parents indicated the most frequent type of a play by themselves, $\chi^{2}(2)=2.651, p$ $=0.266, \eta^{2}=0.06$, and when we defined the type of children's play based on the parent's description, $\chi^{2}(3)=1.973, p=$ $0.578, \eta^{2}=0.045$.

\section{Discussion}

The children's performance in FBT shows that the majority of children aged 5 already understands false belief, which is consistent with previous studies (e.g. Gopnik \& Astington, 1988; Slade \& Ruffman, 2005; Wellman et al., 2001). When we examined the children's performance on PST, we found unexpected results. The children's success was relatively low with all three types of the stories and the children had a lot of difficulties with performing the task. Our findings are not consistent with the previous study (Baron Cohen et al., 1986), both from the point of the children's success at sequencing the pictures into the correct order, and from the point of subsequent analysis of the children's narratives. More precisely, the authors found that children of the same age as the ones in our study are most successful at the intentional story and their narratives are most often classified into the mental category. However, in our study, the children were most successful at the mechanical story and their narratives were most frequently classified as descriptive (except in the case of the behaviour story, where the most common category 
of the narratives was mental). All three stories seemed to be rather difficult for children, which is evident from their average scores and from the percentage of children that correctly sequenced all the pictures of each story. Beside that, more than one third of the children had a specific difficulty with performing this task, because they did not change the sequence of the pictures at all.

The reason for the differences between the children's successfulness at solving different types of stories could be the pictures themselves. If one looks at the pictures more thoroughly, one can see that there is a difference in time sequencing, or better, in the time periods between different pictures in each of the stories. For example, pictures in the behavioural story seem to have a bigger time leap from one picture to another, leaving more room for different ambiguities.

The child's performance on PST is supposed to be a valid indicator of their theory of mind. More specifically, child's correct understanding of the intentional story and his storytelling are claimed to be that indicator (Baron Cohen et al., 1986). However, in our study the children's performance on the intentional story of PST was not significantly correlated to their performance on $F B T$ and, at the same time, the performance on $F B T$ was not significantly correlated to the children's general score on PST. The performance of children on both tasks used for assessing theory of mind shows that a child's success at sequencing pictures into a story is not connected to their false belief understanding even when that story includes the child's understanding of mental states of protagonists. Based on these findings, we cannot claim that the performance on PST is a valid indicator of a child's theory of mind, at least not in the same way as it is assessed with $F B T$. Nevertheless, there is still a possibility that with $P S T$ we are assessing one of the other competences associated with understanding mental states. Astington (2001) emphasizes that the theory of mind is not only the ability of understanding false belief, but it also includes many other competences.

In our study, we found the relation between the performances of children in both storytelling tasks. Additionally, children's scores on BET - understanding and $B E T$ - storytelling are also significantly correlated. This shows that a child's ability to recognize events in a story and to sequence those events into a correct picture order is associated with their ability of storytelling, based on those pictures. However, it is important to stress that the reason for the correlation between the children's scores on BET - understanding and BET - storytelling could be partially found in the ability to memorize the story that was read to them. Evidence for this is that some phrases the children used in storytelling were the same as those in the read version of the story (e.g. "he jumped into the soft bed", "like every night" etc.). What is interesting is that the correlation between the children's performance on BET-understanding and LGST - content was also significant. That is additional evidence of the association between children's successfulness at recognizing the order of events in the story and their storytelling. Their ability to successfully recognize the event order in the story could help them at sequencing events when they are independently telling a story. Additionally, the significant correlation between the children's performance on
LGST - content and BET - storytelling shows that the same competences are needed for storytelling of different stories.

The results showed an association between children's storytelling and their metalinguistic awareness as both LGST - content and BET-storytelling were significantly correlated with the children's scores on $M A S$. More specifically, the number of events the children included in their stories seemed to be especially important in relation to their metalinguistic awareness. Contrarily, children's performance on LGST - grammar and BET - understanding was not significantly correlated with their scores on $M A S$. Based on this evidence, we can conclude that the metalinguistic awareness is related to children's competences to structure the content of a story during the process of storytelling, but not with their competences to grammatically structure the story or their competences to understand and recognize events in a read story. A possible reason for the association between metalinguistic awareness and storytelling is that storytelling, aside from the general language ability, to some extent also requires metalinguistic competences (Charman \& Shmueli Goetz, 1998). For storytelling, a child has to have the representational ability, ability of decentralization, ability to consider various perspectives and to connect events (Marjanovič Umek \& Fekonja Peklaj, 2010). Similarly, for metalinguistic awareness, a child has to have representational ability, so he can understand that language represents meaning in terms of its formal structure (Doherty \& Perner, 1998).

In general, we found that in early childhood the constructs of theory of mind and metalinguistic competences are associated. The children's performance on FBT was significantly correlated with their performance on $M A S$, which is consistent with previous studies (e.g. Doherty, 2000; Doherty \& Perner, 1998; Farrar \& Ashwell, 2012; Ferrar et al., 2005). Metalinguistic awareness is associated with the ability to understand the representational nature of the mind and, consequently, it is also associated with cognitive changes that appear in the development of theory of mind (Doherty \& Perner, 1998). Moreover, the development of false belief understanding should be of special importance for the child's development of metalinguistic awareness (Farrar \& Ashwell, 2012).

We also found evidence for a relation between children's storytelling and their false belief understanding, as the children's performance on both storytelling tasks (LGST and $B E T$ - storytelling) was correlated with their performance on $F B T$, especially from the point of content structure of the story, but not from the point of grammar structure. Specifically, it was found that children's false belief understanding is related to the number of events that they include in their stories. The results are consistent with the assumption that the ability to structure story events is associated with the ability to understand how the mind works and with the ability to mentalize and to infer cognitive mental states (Gamannossi $\&$ Pinto, 2014). Moreover, the reason for the relation between a child's false belief understanding and content structure of a story could be similar competences needed for both. For storytelling, a child has to have the ability of representation and has to be able to consider different perspectives. Often, he has to be able to recognize and connect the protagonist's thoughts and emotions within the story. These competences 
for storytelling are, at the same time, those that are reflected in the story's content structure, e.g. number of events, shifts in perspective and terms for mental states (Marjanovič Umek \& Fekonja Peklaj, 2010). We can see that these competences are to a great extent also competences needed for the theory of mind. For false belief understanding, the child has to develop the ability of representation of other people's beliefs and understand that these beliefs can be wrong. The important part is the ability to understand different perspectives, because this understanding enables a child to form different representations. The only question here is why our results did not show a significant correlation between children's false belief understanding, assessed with $F B T$, and the number of shifts in perspective in their stories in LGST. In contrast to our results, some previous studies confirmed the importance of this relation (e.g. Charman \& Shmueli Goetz, 1998). The reason for this could be the small number of shifts in perspective that children included in their stories in our study, which could cause lower variability of children's scores.

In general, the performance of children on all used tasks is correlated, which consequently shows the importance of the relations between metalinguistic competences and theory of mind in early childhood. Children's false belief understanding, their metalinguistic awareness and their storytelling, especially content structure of the story, are all associated to each other. Through these correlations, the importance of the understanding of representations is shown because all assessed constructs demand the child's ability to understand representations, manipulate with them, understand different perspectives, recognize, structure and sequence events within a specific time frame. All the competences that have in the background the ability to understand the representational nature of the mind seem to be interrelated. In connection with this, some researchers (e.g. Doherty \& Perner, 1998) emphasize the role of theory of mind. When a child develops theory of mind, the understanding of mental states as representations prompts their understanding of nonmental representations as well. The ability of representation, which the child developed within theory of mind, positively affects the development of their metalinguistic competences, including their metalinguistic awareness and their storytelling. Additionally, we discovered that children's understanding of a story assessed with BET-understanding is associated only with their storytelling, and not with their theory of mind or their metalinguistic awareness. This could be the evidence that a child needs some common competences to understand the story and for storytelling, while the understanding of the story alone does not demand the same representational abilities as the theory of mind and metalinguistic awareness. In addition, similar evidence was found for grammatical structure of children's stories, where an absence of significant correlation shows that the grammatical structure of their stories is not related to their competences in the background of theory of mind and metalinguistic awareness.

As a result of the absence of significant correlation between children's performance on FBT and PST, we assume that we did not assess theory of mind with PST, at least not in the same way it is assessed with standard false belief tasks. However, the children's performance on PST was significantly correlated with their performance on tasks used for assessing metalinguistic competences. A child's successfulness at sequencing pictures seems to be associated with the content structure of the story the child can tell, especially with the number of events included into the story. Furthermore, the children's successful sequencing of pictures was associated with their metalinguistic awareness, which could be the evidence that to some extent $P S T$ also demands understanding of representations. The competence of sequencing the pictures as such is claimed to be associated with the competence to recognize and evaluate an internal event structure and with the competence to manipulate with symbolic representations (Zalla et al., 2006).

In our study, we were not able to confirm the relation between children's use of mental state terms and their false belief understanding. The correlations were moderate but neither the number of all used terms nor the number of different used terms was correlated significantly with the children's performance on FBT. A possible explanation for this is that children use mental state terms before they really understand them (Miller, 2006). Consequently, the use of these terms does not mean that a child really understands them, and the ability to understand them is the one that should be important for theory of mind (Antonietti et al., 2006; Moore, Pure, \& Furrow, 1990). In accordance with this, some other studies also failed to find a relation between children's theory of mind and their use of mental state terms in the context of spontaneous speech during symbolic play (Hughes \& Dunn, 1997) and during storytelling (Charman \& Shmueli Goetz, 1998).

Finally, we also examined relations between children's symbolic play, their theory of mind, and their metalinguistic competences. Based on theoretical relations between theory of mind and symbolic play in childhood, as well as evidence from previous studies (e.g. Hughes \& Dunn, 1997; Youngblade \& Dunn, 1995), we predicted that children's theory of mind would be associated to their symbolic play. However, we were not able to confirm this assumption, as children who spent the majority of time in symbolic play did not significantly differ in their performance on $F B T$ from the children who spend the majority of time in other types of play. Furthermore, children who according to their parents spent the majority of time in symbolic play did not differ significantly in their metalinguistic awareness from other children. It is possible the relation between children's theory of mind, their metalinguistic awareness and their symbolic play varies between different stages of symbolic play. The most complex form of symbolic play, the role play, has different demands for a child than other stages and it is more complex, so it could consequently have different effects on children's theory of mind and their metalinguistic competences than the other stages. For example, children's metacommunication increases with increased complexity of symbolic play (Marjanovič Umek \& Lešnik Musek, 1999). We could assume that the metacommunication will be more developed in children that participate in higher stage symbolic play. Nevertheless, Jenkins and Astington (2000) also failed to confirm the relation between children's theory of mind and their symbolic play. On the other hand, it could be possible that we did not find any differences because of the way we gather information about children's most frequent play. Based 
on inconsistencies we found between parents' answers, these answers could be unreliable and consequently problematic.

Our study had some limitations. The size of the sample was rather small, which limits generalizability of our results. In addition, the possible problem is also the way we assessed theory of mind. We used only one standard false belief task, which caused the ceiling effect and decreased the sensibility of the assessment. The performance of children on standard and on non-standard tasks for assessing theory of mind was not related. This lead to additional questions about the way and the extent each of the tasks assessed theory of mind. The last important limitation refers to the way we gathered information about the children's most typical play. It has been found that the information gathered with a questionnaire is insufficient, especially because of inconsistencies between information gathered with different questions, and that some other type of information gathering should be used (e.g. direct observation in a child's everyday environment).

To conclude, our findings reflect the relation between theory of mind and metalinguistic competences in early childhood quite well. Based on these findings, we can emphasize the importance of a child's understanding, forming and manipulation of representations for different aspects of their everyday behaviour. Theory of mind and metalinguistic competences are crucial for children, and their common demands for understanding the representations highlight the meaning of the symbolically rich environment that promotes the understanding and forming of these representations. Further research should examine whether there are some competences within metalinguistic awareness that are especially associated with children's theory of mind. Likewise, the role of the metavocabulary and symbolic play in the development of theory of mind in the early childhood should be examined.

\section{References}

Antonietti, A., Liverta-Sempio, O., Marchetti, A., \& Astington, J. W. (2006). Mental language and understanding of epistemic and emotional mental states. In A. Antonietti, O. Liverta-Sempio and A. Marchetti (Eds.), Theory of mind and language in developmental contexts, (pp. 130). New York, NY, USA: Springer Science+Business Media.

Applebee, A. N. (1978). The child's concept of story. Chicago, IL, USA: University of Chicago Press.

Astington, J. W. (2001). The future of theory-of-mind research: Understanding motivational states, the role of language, and real-world consequences. Child development, 72(3), 685-687.

Astington, J. W., \& Jenkins, J. M. (1999). A longitudinal study of the relation between language and theory-ofmind development. Developmental Psychology, 35(5), 1311-1320.

Baron Cohen, S., Leslie, A. M., \& Frith, U. (1985). Does the autistic child have a »theory of mind «? Cognition, 21, 37-46.
Baron Cohen, S., Leslie, A. M., \& Frith, U. (1986). Mechanical, behavioural and intentional understanding of picture stories in autistic children. British Journal of Developmental Psychology, 4, 113-125.

Bloom, P., \& German, T. P. (2000). Two reasons to abandon the false-belief task as a test of theory of mind. Cognition, 77, 25-31.

Call, J., \& Tomasello, M. (1999). A nonverbal false belief task: The performance of children and great apes. Child Development, 70(2), 381-395.

Charman, T., \& Shmueli Goetz, Y. (1998). The relationship between theory of mind, language, and narrative discourse: An experimental study. Cahiers de Psychologie Cognitive/Current Psychology of Cognition, 17(2), 245-271.

Cutting, A. L., \& Dunn, J. (1999). Theory of mind, emotional understanding, language, and family background: Individual differences and interrelations. Child development, 70(4), 853-865.

de Villiers, J. (2007). The interface of language and theory of mind. Lingua, 117, 1858-1878.

de Villiers, J., \& de Villiers, P. (1972). Early judgements of semantic and syntactic acceptability by children. Journal of Psycholinguistic Research, 1, 299-310.

Doherty, M. (2000). Children's understanding of homonymy: Metalinguistic awareness and FB. Journal of Child Language, 27(2), 367-392.

Doherty, M., \& Perner, J. (1998). Metalinguistic awareness and theory of mind: Just two words for the same thing? Cognitive Development, 13, 279-305.

Farrar, M. J., \& Ashwell, S. (2012). Phonological awareness, executive functioning, and theory of mind. Cognitive Development, 27, 77-89.

Farrar, M. J., Ashwell, S., \& Maag, L. (2005). The emergence of phonological awareness: Connections to language and theory of mind development. First language, 25(2), 157-172.

Fekonja, U. (2009). Razvoj otroške igre [Child play development]. In L. Marjanovič Umek \& M. Zupančič (Eds.), Razvojna psihologija [Developmental psychology] (pp. 382-393). Ljubljana, Slovenia: Znanstveni inštitut Filozofske fakultete.

Gamannossi, B. A., \& Pinto, G. (2014). Theory of mind and language of mind in narratives: Developmental trends from kindergarten to primary school. First language, 34(3), 262-272.

Gopnik, A., \& Astington, J. W. (1988). Children's understanding of representational change and its relation to the understanding of false belief and the appearancereality distinction. Child development, 59, 26-37.

Hughes, C., \& Dunn, J. (1997). "Pretend you didn't know": Preschoolers' talk about mental states in pretend play. Cognitive Development, 12, 477-499.

Hughes, C., \& Dunn, J. (1998). Understanding mind and emotion: Longitudinal associations with mental-state talk between young friends. Developmental Psychology, 34, 1026-1037. 
Jenkins, J. M., \& Astington, J. W. (1996). Cognitive factors and family structure associated with theory of mind development in young children. Developmental Psychology, 32, 70-78.

Jenkins, J. M., \& Astington, J. W. (2000). Theory of mind and social behaviour: Causal models tested in a longitudinal study. Merrill-Palmer Quaterly, 46(2), 203-220.

Leslie, A. M. (1987). Pretense and representation: The origins of »Theory of mind«. Psychological Review, 94(4), 412-426.

Marjanovič Umek, L. (2009). Spoznavni razvoj v zgodnjem otroštvu [Cognitive development in early childhood]. In L. Marjanovič Umek \& M. Zupančič (Eds.), Razvojna psihologija [Developmental psychology] (pp. 291-314). Ljubljana, Slovenia: Znanstveni inštitut Filozofske fakultete.

Marjanovič Umek, L., \& Fekonja, U. (2009). Razvoj govora $\mathrm{V}$ zgodnjem otroštvu [Speech development in early childhood]. In L. Marjanovič Umek \& M. Zupančič (Eds.), Razvojna psihologija [Developmental psychology] (pp. 315-333). Ljubljana, Slovenia: Znanstveni inštitut Filozofske fakultete.

Marjanovič Umek, L., \& Fekonja Peklaj, U. (2010). The role of symbolic play in early literacy development. Journal of Communications Research, 1(4), 291-308.

Marjanovič Umek, L., Fekonja, U., Podlesek, A., Kranjc, S, \& Bajc, K. (2007). Lestvice splošnega govornega razvoja - LJ (LSGR - LJ): Priročnik [Scales of general language development - LJ: Manual]. Ljubljana, Slovenia: Center za psihodiagnostična sredstva.

Marjanovič Umek, L., Fekonja Peklaj, U., Sočan, G., \& Komidar, L. (2011). Pripovedovanje zgodbe: Preizkus pripovedovanja zgodbe: Rokavicka: Preizkus pripovedovanja zgodbe: Žabji kralj: Priročnik [Storytelling: Storytelling test: The Little glove: Storytelling test: The Frog king: Manual]. Ljubljana, Slovenia: Center za psihodiagnostična sredstva.

Marjanovič Umek, L., \& Lešnik Musek, P. (1999). Simbolna igra: Kaj jo določa in kako igra določa otrokov razvoj [Symbolic play: What determines it and how the play determines the child's development]. Psihološka obzorja, 8(2-3), 3-58.
Miller, C. A. (2006). Developmental relationships between language and theory of mind. American Journal of Speech-Language Pathology, 15, 142-154.

Milligan, K., Astington J. W., \& Dack, L. A. (2007). Language and theory of mind: Meta-analysis of the relation between language ability and false-belief understanding. Child development, 78(2), 622-646.

Moore, C., Pure, K., \& Furrow, D. (1990). Children's understanding of the modal expression of speaker certainty and uncertainty and its relation to the development of a representational theory of mind. Child development, 61, $722-730$.

Perner, J. (1991). Understanding the representational mind. Cambridge, MA, USA: Bradford Books/MIT Press.

Perner, J., Baker, S., \& Hutton, D. (1994). Prelief: The conceptual origins of belief and pretence. In C. Lewis and P. Mitchell (Eds.), Children's early understanding of mind: Origins and development (pp. 261-286). Hove, United Kingdom: Lawrence Erlbaum Associates.

Perner, J., Stummer, S., Sprung, M., \& Doherty, M. (2002). Theory of mind finds its Piagetian perspective: Why alternative naming comes with understanding belief. Cognitive Development, 17, 1451-1472.

Slade, L., \& Ruffman, T. (2005). How language does (and does not) relate to theory of mind: A longitudinal study of syntax, semantics, working memory and false belief. British Journal of Developmental Psychology, 23, 117-141.

Wellman, H. M., Cross, D., \& Watson, J. (2001). Meta-analysis of theory of mind development: The truth about falsebelief. Child Development, 72, 655-684.

Wimmer, H., \& Perner, J. (1983). Beliefs about beliefs: Representation and constraining function of wrong beliefs in young children's understanding of deception. Cognition, 13, 103-128.

Youngblade, L. M., \& Dunn, J. (1995). Individual differences in young children's pretend play with mother and siblings: Links to relationship and understanding of other people's feelings and beliefs. Child Development, 66, 1472-1492.

Zalla, T., Bouchilloux, N., Labruyere, N., Georgieff, N., Bougerol, T., \& Franck, N. (2006). Impairment in event sequencing in disorganised and non-disorganised patients with schizophrenia. Brain Research Bulletin, 68, 195-202. 